in "Zwei Jahre auf Kamtschatka" (1911) and in "Voyage en Kamtchatka en 1908-1909", forming part of the official account of the expedition (1913). During 1931-32, in collaboration with MIme. Klobukova-Alisova, Komarov published a "Key to the Plants of the Far Eastem Region of the U.S.S.R." in two volumes, and in 1934 appeared the first volume of the magnificently conceived and executed "Flora U R S S". This truly monumental work, of which at least seven volumes havo already appeared in rapid succession, is the result of the collaboration of numerous Russian botanists under Komarov's general editorship. Wo sincerely trust that Prof. IKomarov may live to see the completion of his crowning work.

\section{German Culture in Prague}

A nepont from the Protectorate of Bohemia and Moravia announces that tho German University of Prague has been reconstituted as a Reichsdeutsch University "to servo as a centro for German cultural expansion to the south-east of Europe". This status was made legal on October 1 and necessitates the appointment of Nazi professors to Prague. They are to be accompanied by $a$ large body of students drawn from all parts of Germany. In the past, this German university in Czechoslovakia attracted many well. known specialists from Germany and Austria. Indeed, it was the policy of the former Czech Ministry of Education to encourage such appointments in order to ensure a high standard both of teaching and scientific research. The now appointments are, however, avowedly not for scientific advancement but for Germanization, a process that is being pursued also by the schools throughout the protectorate as well as in the Sudeten territory acquired by Germany in September 1938. Meanwhile, Czech and non-Nazi professors aro drafted into labour corps. A number have succumbed to this inhuman treatment, including Profs. Charrat and Berlohradek. Despite the deplorable setback to science and learning in Central Europe, the Czechs are still attempting to continue with their investigations. An instance is afforded by the recent archaological excavations near Mrlnik, where a prehistoric settlement has been unearthed. The objects discovered are believed to date from the time when Slav tribes first settled in the Elbe valley.

\section{The Linnean Society}

Is addressing the Linnean Society of London meeting on October 26, the president, Dr. J. Ramsbottom, said that the Council had already taken steps before May last to protect the Society's treasures ; the Linnean collections (specimens and books) were moved, and the medals and other valuables from the Iron Chest. Since the outbreak of hostilities the Smithian Herbarium and some smaller collections have been moved and stored in what is hoped to be a safo place. It is the unanimous decision of the Council that the Society should carry out its normal activities so far as is possible. This is in the best interest of fellows, of the Society, and of the subjects in which the Society is interested. Apart from the communications at meetings it is essential that biologists should have an opportunity for informal meeting at some central place in London. Therefore the Society is keeping its rooms open and allowing them to be used by other societies or bodies of bio. logists who are in need of such $\approx$ meeting-place either for formal or informal discussions. In 1914 the time of meeting was altered from 7 o'clock to 5 o'clock because of moonlight nights-moonlight nights had been favoured in the early days of the Society, before streets wero properly lighted. Now becauso of the black-out it is necessary to hold meetings earlier. The next meeting will be held at 2.30 and the follow. ing-summer-time being ended-at 2.15.

\section{Museums and the War}

ON the outbreak of war many museums were closed to tho public, following tho example of the various national museums under Government control. It was a regrettable move on the part of the Govern. ment, for these institutions are centres of education and mild recreation, as well as repositories of valuable specimens, and the use of them rould have been a welcome relief from more stern affairs to many of the public and the troops. Now in a pamphlet issued by the Board of Education, entitled "The Schools in War-time" (Memorandum No. 4), "The Use of Museums" is discussed, and wo have tho curious spectacle of the president of the Board of Education urging the value in war-time of museums and urging the use of museums, whilo those museums over which he has some measure of control remain closed. Nevertheless the policy which he urges in this pamphlet is the right one, and War Circular No. 1 of the Museums Association on "Museums and the War" gives a lead. Not only is it desirable, according to this circular, that existing museum services should continue, but also that additional educational services should be provided. Ways aro shown in which museums can help. It is probable that in many cases reduction of staffs may render special efforts impossible; but it is not a serious matter to make halls and galleries, as many as the number of attendants will allow, available for the public.

\section{The Electrical Grid in Great Britain}

Is viow of the decision of the Institution of Electrical Engineers to hold no meetings of the Institution in London during the first half of the session, a copy of the address of Mr. Johnstone Wright, president of the Institution and chairman of the Central Electricity Board, which he would have delivered normally on October 26 , has been posted to every member in the United Kingdom and Eire. His choice of the construction and operation of the Grid as the subject of his address was a happy one, owing to the significant coincidence that the incoming president on the outbreak of the War of 1914-18 was the Inte Sir John Snell, to whose vision, enthusiasm and advocacy the Grid is so Iargely due. The deficiencies in national electrical organization revealed by that war resulted in the establishment of the Grid. It is not too much to claim that the Grid has a vital national role in the present struggle. The Grid con- 